\title{
IDENTIFIKASI MOLEKULER SIRIP IKAN HIU YANG DIDAPAT DARI PENGUMPUL SIRIP DI MINAHASA
}

\author{
(Molecular Identification of Shark Fins Collected from Fins Collectors in Minahasa)
}

\section{Maratade Mopay $^{1^{\star}}$, Stenly Wullur ${ }^{1}$, Erly Kaligis ${ }^{1}$,}

1. Program Studi IImu Kelautan, Fakultas Perikanan dan IImu Kelautan, Universitas Sam Ratulangi, Manado.

*e-mail :maratademopay@gmail.com

Sharks are highly vulnerable to the overfishing due to their slow growth and low reproductive rate. The high trade activity became a serious problem in maintaining the balance of marine ecosystems. Present study aimed to identify shark fins fin obtained from fin collectors in Tanawangko, Minahasa based on COI (Cytrochrome oxidase subunit $l$ ) gene. DNA extraction was done following procedure Dneasy Blood \& Tissue Kit qiagen, COI gene was amplified using primers primer Forward FishBCL5 (TCAACYAATCAYAAAGATATYGGCAC) and Reverse HCO2198 (TAAACTTCAGGGTGACCA AAAAATCA), sequences were analyzed using ABsequence3 and MEGA ver6, species identification was conducted using BLAST integrated in GenBank. A number of 4 shark fins were successfully collected from fin collectors in Tanawangko, Minahasa. BLAST results showed that the 4 fins were belong to species; Carcharhinus amblyrhynchos, Prionace glauca, Carcharhinus sorrah, dan Carchahinus brevipina

Keywords: Shark, fin, COI, Collector, Minahasa

Hiu adalah jenis ikan yang sangat rentan terhadap penangkapan secara berlebihan karena umumnya ikan ini memiliki pertumbuhan yang lambat dan tingkat reproduksi yang rendah. Tingginya aktifitas perdagangan sirip ikan hiu menjadi masalah serius dalam menjaga keseimbangan ekosistem laut. Penelitian ini bertujuan untuk mengidentifikasi sirip ikan hiu yang didapat dari pengumpul sirip di Tanawangko, Minahasa berdasarkan karakter nukleotida gen COI (Cytcrochrome oxidase subunit I). Metode ekstraksi DNA dilakukan mengikuti prosedur Dneasy Blood \& Tissue Kit qiagen, amplifikasi gen $\mathrm{COI}$ menggunakan primer Forward FishBCL5 (TCAACYAATCAYAAAGATATYGGCAC) dan Reverse HCO2198 (TAAACTTCAGGGTGACCA AAAAATCA), sekuens dianalisa menggunakan ABsequence3 dan MEGA ver6, identifikasi spesies dilakukan menggunakan BLAST yang terintegrasi di laman GanBank. Sebanyak 4 potong sirip hiu dari individu berbeda berhasil didapatkan dari pengumpul sirip di Tanawangko, Minahasa. Hasil BLAST menunjukan bahwa ke 4 sirip tersebut berasal dari spesies hiu; Carcharhinus amblyrhynchos, Prionace glauca, Carcharhinus sorrah, dan Carchahinus brevipina

Kata Kunci: Ikan Hiu, Sirip, COI, Collector, Minahasa

\section{PENDAHULUAN}

Hiu adalah jenis ikan yang sangat rentan terhadap dampak penangkapan secara berlebihan karena umumnya ikan ini memiliki pertumbuhan yang lambat dan memerlukan waktu yang lama untuk berkembang biak. Jenis ikan ini membutuhkan waktu sekitar 50-70 tahun untuk mencapai usia dewasa dan berkembang biak. Dilaporkan pula bahwa ikan ini, hanya mampu menghasilkan jumlah anak yang relatif sedikit dibandingkan dengan kelompok ikan yang bernilai ekonomis lainnya (White et al, 2010).

Tingginya aktifitas perdagangan sirip ikan hiu menjadi masalah serius dalam menjaga keseimbangan ekosistem laut sehubungan dengan lambatnya perkembangbiakan hiu yang 
berdampak pada penurunan populasi hiu yang signifikan dari tahun ke tahun (Mundy et al. 2013). Menghadapi masalah tersebut, berbagai kebijakan dalam tingkatan internasional, nasional hingga daerah telah dibuat untuk mengendalikan perburuan ikan hiu hingga perdagangan sirip ikan hiu. Akan tetapi, ikan hiu pada umumnya didaratkan dalam bentuk potongan tubuh setelah melalui proses fining pemisahan sirip dan bagian tubuh ikan (hiu), sehingga menjadi kendala serius dalam proses pengenalan spesies. Kesulitan yang sama dialami pula dalam kegiatan perdagangan sirip ikan hiu, yang mana objek yang digunakan sebagai acuan pengenalan spesies hanya berupa potongan sirip yang sulit untuk dikenali/identifikasi spesiesnya, dari data yang dipublikasikan Red list fauna data IUCN (internasional Union for Conservation of nature) menunjukan ikan hiu telah dikategorikan spesies terancam punah.

DNA barcode merupakan salah satu pendekatan molekuler baru yang efektif diaplikasikan dalam upaya pengenalan atau identifikasi spesies, khususnya dari objek berupa potongan organ suatu individu, seperti sirip ikan hiu (Ward et., al, 2009). Metode ini menggunakan urutan pendek segmen DNA yang ada di mitokondria, yaitu gen Cytochrome oxidase subunit I (COI) sebagai dasar analisis identifikasi spesies (Hebert et al., 2003). Metode ini hanya membutuhkan potongan sampel yang sangan sedikit/kecil dari suatu organisme yang akan diidentifikasi dan memiliki tingkat akurasi yang tinggi dalam membedakan spesies (Holmes et al., 2008). Penelitian ini dilakukan untuk mengidentifikasi sirip ikan hiu yang didapat dari pengumpul yang ada di Kabupaten Minahasa melalui pendekatan molekuler.

\section{METODE PENELITIAN}

Pengambilan sampel dilakukan di desa Tanawangko, Kabupaten
Minahasa. Analisis molekuler dilakukan di Laboratorium Biologi Molekuler dan Farmasitika Laut, Fakultas Perikanan dan IImu Kelautan Universitas Sam Ratulangi Manado.

Sampel sirip ikan hiu yang digunakan dalam penelitian ini adalah sampel sirip punggung. Pemilihan potongan sirip punggung dilakukan untuk menghindari terjadinya kekeliruan pengambilan sampel pada individu yang sama. Sampel sirip punggung ikan hiu kemudian direndam dalam air selama kurang lebih 1 jam hingga tekstur jaringannya menjadi lembek. Tahap Isolasi DNA genom dilakukan dengan menggunakan bantuan Dneasy Blood \& Tissue kit qiagen dan prosedur isolasi DNA berpatokan pada prosedur pabrikan Dneasy protocol (www.qiagen. com). Sampel sirip ikan hiu sebanyak $50 \mathrm{mg}$, dilisis menggunakan buffer ATL dan DNA total dari sampel dipisahkan dari protein dan debris menggunakan proteinase $\mathrm{K}$ dan buffer AL. DNA total dikoleksi menggunakan Dneasy mini spin kolom dilanjutkan dengan proses pemurnian DNA menggunakan buffer AW1 dan AW2.DNA total yang terkoleksi dalam spin filter dipindahkan ke elution tube yang telah disiapkan dengan menggunakan buffer $A E$.

Amplifikasi gen $\mathrm{COI}$ dilakukan dengan menggunakan bantuan mesin PCR. Primer yang digunakan untuk mengamplifikasi gen COI Forward Fish BCL5 (TCAACYAATCAYAAAGATATYGGAC) dan primer reverse, HCO2198 (TAAACTTCAGGGTGACCAAAAAATC A) (Peloa. 2015). Amplifikasi gen dilakukan dengan menggunakan $5 \mathrm{x}$ HOT Firepol Master Mix. Total volume yang digunakan untuk amplifikasi adalah $25 \mu \mathrm{L}$, yang terdiri atas $1 \mu \mathrm{L}$ DNA sampel dan $1 \mu \mathrm{L}$ volume dari masing-masing primer. Amplifikasi DNA menggunakan mesin PCR TPersonal (Biometra) dengan pengaturan suhu sebagai berikut: predenaturasi pada suhu $95^{\circ} \mathrm{C}$ selama 2 menit, denaturasi pada $95^{\circ} \mathrm{C}$ selama 40 detik yang dilakukan sebanyak 37 
siklus, annealing pada suhu $50^{\circ} \mathrm{C}$ selama 40 detik yang dilakukan sebanyak 37 siklus, elongasi pada suhu $72^{\circ} \mathrm{C}$ selama 40 detik yang dilakukan sebanyak 37 siklus dan 1 siklus perpanjangan akhir pada suhu $72^{\circ} \mathrm{C}$ selama 1 menit. Keberhasilan amplifikasi gen COI selanjutnya diperiksa menggunakan teknik gel elektroforesis. Gel yang digunakan adalah gel berkonsentrasi $1 \%$ yang ditambahkan dengan maestrosafe prestained sebanyak $2 \mu \mathrm{L}$. Produk amplifikasi DNA sebanyak $4 \mu \mathrm{L}$ dan 1 $\mu \mathrm{L} 10 \mathrm{x}$ loading buffer dimasukkan dalam masing-masing sumur yang telah disiapkan dalam gel.

$$
\text { Hasil pemeriksaan gel }
$$

elektroforesis diamati lewat sinar UV transluminator yang diikuti dengan dokumentasi menggunakan kamera digital. Produk amplifikasi yang menunjukan adanya pita pada panjang basa sekitar 600-700 bp dikirim ke jasa pelayanan sekuensing FIRST BASE, Malaysia. Hasil sekuens dari sampel sirip ikan hiu didapat dalam bentuk format chromatogram, yang terdiri dari hasil sekuens sample forward dan reverse.

Kualitas hasil sekuens dianalisis menggunakan aplikasi ABsequence3, dimana kualitas hasil sekuens (urutan nukleotida) ditentukan berdasarkan pada $\mathrm{QV}^{+20}$ (quality value lebih besar dari 20) dan $C R L$ (contignous read length). $\mathrm{QV}^{+20}$ adalah nukleotida yang memiliki nilai kualitas hasil sekuens lebih dari 20, sedangkan CRL adalah deretan panjang nukleotida kualitas baik (>20) yang tak terpotong. Karakter nukleotida gen $\mathrm{COI}$ dianalisis dengan menggunakan program software MEGA versi 6.

Identifikasi sirip ikan hiu dilakukan berdasarkan karakter nuklotida gen COI dari masing-masing sampel. Pengolahan data nukleotida hasil sekuens menggunakan perangkat computer sebagai alat penunjang utama yang sudah dilengkapi dengan konektifitas internet. Identifikasi spesies dilakukan dengan mencocokan data nukleotida sampel dengan data nukleotida yang terdokumentasi di laman Gen bank NCBI (National Centre for Biotechnology Information) (www.ncbi.nlm.nih.gov/genbank).

Metode pencocokan dilakukan dengan menggunakan teknik BLAST yang ada di laman tersebut. Penentuan status konservasi dari spesies yang berhasil teridentifikasi, dilakukan secara online dengan mengakses laman IUCN red list (www.iucn.org).

\section{HASIL DAN PEMBAHASAN}

Total sirip yang diperoleh dari pengumpul sirip di Tanawangko Minahasa, berjumlah 4 buah sirip punggung dengan kode sirip HT-1, HT2, HT-3 dan HT-4 (Gambar 1)

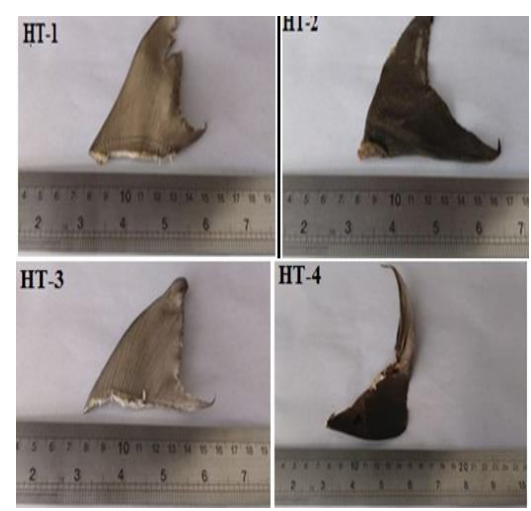

Gambar 1. Bentuk dan tampakan sirip punggung ikan hiu yang didapat pengumpul di Tanawangko, Kabupaten Minahasa.

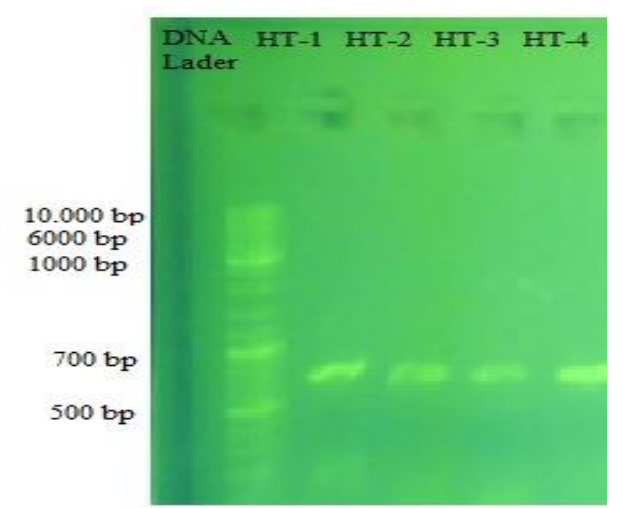

Gambar 2. Visualisasi hasil amplifikasi gen COI sirip ikan hiu dari Tanawangko (HT1, HT2, HT3, HT4) 
Tabel 1. Kualitas hasil sekuens sirip ikan hiu yang dianalisis menggunakan program ABsequense. CRL (continuous read length) dan QV (quality value 20+).

\begin{tabular}{lllll}
\hline No & $\begin{array}{l}\text { Kode } \\
\text { Sampel }\end{array}$ & Primer & CRL & QV20+ \\
\hline 1 & HT-1 & For & 651 & 660 \\
& & Rev & 650 & 649 \\
\hline 2 & HT-2 & For & 653 & 655 \\
& & Re & 659 & 662 \\
\hline 3 & HT-3 & For & 659 & 653 \\
& & Re & 658 & 656 \\
\hline 4 & HT-4 & For & 649 & 656 \\
& & Re & 652 & 657 \\
\hline
\end{tabular}

Tabel 2. Cuplikan hasil penelusuran teratas menggunakan sekuens gen COI sirip hiu kode HT-1, HT_2, HT-3 dan HT-4 yang didapat dari pengumpul di Minahasa.

\begin{tabular}{|c|c|c|c|c|c|c|}
\hline Description & $\begin{array}{l}\text { Max } \\
\text { Score }\end{array}$ & $\begin{array}{l}\text { Total } \\
\text { Score }\end{array}$ & $\begin{array}{l}\mathrm{E}- \\
\text { value }\end{array}$ & $\begin{array}{l}\text { Query } \\
\text { cover }\end{array}$ & Identity & Accession \\
\hline \multicolumn{7}{|l|}{ Sirip hiu kode HT-1 } \\
\hline $\begin{array}{l}\text { Carcharhinus amblyrhynchos } \\
\text { voucher SOSSRC:Carcharhinus } \\
\text { amblyrhynchos OC-70 } \\
\text { cytochrome oxidase subunit } 1 \\
\text { (COI) gene, partial cds: } \\
\text { mitochondrial }\end{array}$ & 1205 & 1205 & 0.0 & $95 \%$ & $100 \%$ & FJ519196.1 \\
\hline $\begin{array}{l}\text { Carcharhinus amblyrhynchos } \\
\text { voucher voucher IBRC.01.77.03 } \\
\text { cytochrome oxidase subunit } \\
1(\mathrm{COI}) \text { gene, partial cds : } \\
\text { mitochondrial }\end{array}$ & 1203 & 1203 & 0.0 & $95 \%$ & $99 \%$ & KF590385.1 \\
\hline $\begin{array}{l}\text { Carcharhinus amblyrhynchos } \\
\text { voucher BW-A2525 cytochrome } \\
\text { oxidase subunit } 1 \text { (COI) gene, } \\
\text { partial cds : mitochondrial }\end{array}$ & 1203 & 1203 & 0.0 & $95 \%$ & $99 \%$ & EU398594.1 \\
\hline $\begin{array}{l}\text { Carcharhinus amblyrhynchos } \\
\text { voucher BIOUG<CAN>BW- } \\
\text { A3018 cytochrome oxidase } \\
\text { subunit } 1 \text { (COI) gene, partial } \\
\text { cds, mitochondrial }\end{array}$ & 1199 & 1199 & 0.0 & $95 \%$ & $99 \%$ & EU398597.1 \\
\hline $\begin{array}{l}\text { Carcharhinus amblyrhynchos } \\
\text { voucher BW-A2522 cytochrome } \\
\text { oxidase subunit } 1 \text { (COI) gene, } \\
\text { partial cds: mitochondrial }\end{array}$ & 1199 & 1199 & 0.0 & $95 \%$ & $99 \%$ & EU398596.1 \\
\hline \multicolumn{7}{|l|}{ Sirip hiu kode HT-2 } \\
\hline $\begin{array}{l}\text { Prionace qlauca mitochondrion } \\
\text { complete genome }\end{array}$ & 1267 & 1267 & 0.0 & $100 \%$ & $99 \%$ & KF356249.1 \\
\hline $\begin{array}{l}\text { Prionace qlauca cytochrome } \\
\text { oxidase subunit } 1 \text { gene, } \\
\text { complete cds : mitochondrial }\end{array}$ & 1267 & 1267 & 0.0 & $100 \%$ & $99 \%$ & JQ654713.1 \\
\hline $\begin{array}{lc}\text { Carcharodon } & \text { carcharias } \\
\text { cytochrome oxidase subunit } 1 \\
\text { gene. complete cds } \\
\text { mitochondrial }\end{array}$ & 1256 & 1256 & 0.0 & $100 \%$ & $99 \%$ & JQ654702.1 \\
\hline Prionace & 1212 & 1212 & 0.0 & $95 \%$ & $99 \%$ & KJ146042.1 \\
\hline
\end{tabular}




\begin{tabular}{|c|c|c|c|c|c|c|}
\hline $\begin{array}{l}\text { GVH2121 cytochrome oxidase } \\
\text { subunit I (COI) gene, partial cds } \\
\text { : mitochondrial }\end{array}$ & & & & & & \\
\hline $\begin{array}{l}\text { Prionace qlauca voucher } \\
\text { BIOUG<CAN>BW-A073 } \\
\text { cytochrome oxidase subunit } 1 \\
\text { (COI) gene, partial cds : } \\
\text { mitochondrial }\end{array}$ & 1210 & 1210 & 0.0 & $94 \%$ & $100 \%$ & DQ108285.1 \\
\hline \multicolumn{7}{|l|}{ Sirip hiu kode HT-3 } \\
\hline $\begin{array}{lr}\text { Carcharhinus } & \text { sorrah } \\
\text { mitochondrion } & \text { complete } \\
\text { genome } & \end{array}$ & 1267 & 1267 & 0.0 & $99 \%$ & $99 \%$ & KF612341.1 \\
\hline $\begin{array}{l}\text { Carcharhinus sorrah voucher } \\
\text { IBRC } 011801 \text { cytochrome } \\
\text { oxidase subunit } 1(\mathrm{COI}) \text { gene, } \\
\text { partial cds : mitochondrial }\end{array}$ & 1208 & 1208 & 0.0 & $94 \%$ & $100 \%$ & KC840949.1 \\
\hline $\begin{array}{l}\text { Carcharhinus sorrah voucher } \\
\text { SOSSRC Carcharhinus sorrah } \\
\text { OC-7 cytochrome oxidase } \\
\text { subunit I (COI) gene, partial cds } \\
\text { : mitochondrial }\end{array}$ & 1205 & 1205 & 0.0 & $93 \%$ & $100 \%$ & FJ519167.1 \\
\hline $\begin{array}{l}\text { Carcharhinus sorrah voucher } \\
\text { IBRC011802 cytochrome } \\
\text { oxidase subunit } 1(\mathrm{COI}) \text { gene, } \\
\text { partial cds : mitochondrial }\end{array}$ & 1203 & 1203 & 0.0 & $94 \%$ & $99 \%$ & KC840950.1 \\
\hline $\begin{array}{l}\text { Carcharhinus sorrah voucher } \\
\text { NBFGR:CHN:SK14 cytochrome } \\
\text { c oxidase subunit I (COI) gene, } \\
\text { partial cds : mitochondrial }\end{array}$ & 1199 & 1199 & 0.0 & $94 \%$ & $99 \%$ & KF899818.1 \\
\hline \multicolumn{7}{|l|}{ Sirip hiu kode HT-4 } \\
\hline $\begin{array}{lr}\text { Carcharhinus } & \text { brevipinna } \\
\text { mitochondrion, } & \text { complete } \\
\text { genome } & \end{array}$ & 1273 & 1273 & 0.0 & $99 \%$ & $99 \%$ & KM244770.1 \\
\hline $\begin{array}{l}\text { Carcharhinus } \\
\text { voucher BW-A2529 cytochrome } \\
\text { oxidase subunit } 1 \text { (COI) gene, } \\
\text { partial cds: mitochondrial }\end{array}$ & 1210 & 1210 & 0.0 & $94 \%$ & $100 \%$ & EU398602.1 \\
\hline $\begin{array}{l}\text { Carcharhinus } \\
\text { voucher FDA } 102 \text { cytochipinna } \\
\text { oxidase subunit } 1(\mathrm{COI}) \text { gene, } \\
\text { partial cds : mitochondrial }\end{array}$ & 1208 & 1208 & 0.0 & $94 \%$ & $100 \%$ & KF461149.1 \\
\hline 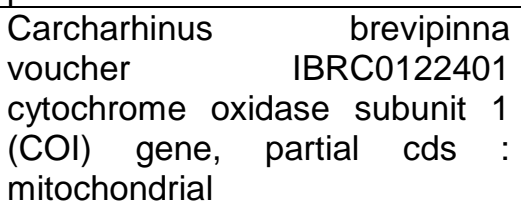 & 1208 & 1208 & 0.0 & $94 \%$ & $100 \%$ & KF793760.1 \\
\hline $\begin{array}{l}\text { Carcharhinus } \\
\text { voucher BW-A2530 cytochrome } \\
\text { oxidase subunit } 1(\mathrm{COI}) \text { gene, } \\
\text { partial cds: mitochondrial }\end{array}$ & 1208 & 1208 & 0.0 & $94 \%$ & $100 \%$ & EU398601.1 \\
\hline
\end{tabular}


Hasil amplifikasi gen COI dari keseluruhan sampel sirip ikan hiu (4 buah sampel) ditampilkan pada Gambar 2. Visualisasi hasil amplifikasi gen COI dari semua sampel sirip ikan hiu menunjukan adanya pita- pita DNA yang jelas dan tebal pada masingmasing lintasan sampel yang teramati pada posisi sekitar 700 bp gel elektroforesis menggunakan $10.000 \mathrm{bp}$ DNA ladder sebagai pembanding. Hasil penelitian ini sama dengan yang dilaporkan oleh Peloa dkk (2015) yang menggunakan sampel sirip ikan hiu. Hebert et al $\left(2003^{\mathrm{a}}\right)$ juga melaporkan posisi pita gen COI yang sama pada berbagai jenis avertebrata laut, yang mana pita DNA gen COI muncul pada posisi sekitar $700 \mathrm{bp}$.

Kualitas hasil sekuens gen $\mathrm{COI}$ dari keseluruhan sirip hiu menunjukan nilai $C R L$ dan $\mathrm{QV}^{+20}$ yang tinggi (> 600 nukleotida) (Tabel 1). Hasil Nucleotida BLAST pada laman GenBank menggunakan DNA konsensus HT-1 mendapatkan 100 laporan sekuens yang mirip dengan data yang ada di bank gen dengan tingkat kemiripan tinggi (skor $>=200$ nukelotida). Hasil BLAST sekuens gen COI sirip hiu kode HT-1, HT-2, HT-3 dan HT-4, masing masing merujuk pada spesies Carcharhinus amblyrhynchos, Prionace qlauce, Carcharhinus sorrah dan Carcharhinus brevipinna. Skor keakuratan sekuens sirip hiu dalam penelitian ini dengan data yang ada di GenBank menunjukan tingkat keakuratan yang tinggi, terlihat dari skor maksimum dan skor total $(>1000$ nukleotida), query cover (>93\%), Evalue $(0.0)$, dan percent identity (>99\%).

Status konservasi berdasarkan data IUCN redlist dari keseluruhan spesies yang teridentifikasi dalam penelitian ini adalah near threatened (NT) atau hampir terancam

\section{KESIMPULAN}

Hasil identifikasi molekuler 4 sampel sirip hiu yang didapat dari pengumpul yang ada di Minahasa merujuk pada 4 spesies ikan hiu yang berbeda, yaitu; Carcharhinus amblyrhynchos, Prionace qlauce, Carcharhinus sorrah dan Carcharhinus brevipinna. Hasil akses data status konservasi menurut situs IUCN redlist, menempatkan keempat spesies tersebut dalam kategori Near Threatened (NT) atau hamper terancam.

\section{DAFTAR PUSTAKA}

Hebert, P.D., Cywinska, A., Ball, . S. L. $2003^{a}$. Biological indetifications through DNA barcodes. Proceedings of the Royal Society of London B: Biological Science, 270(512), 313-321.

Hebert, P.D., Ratnasingham, S., Ward, R.D. $2003^{\mathrm{b}}$. Barcoding animal life: cytochrome c oxidase subunit 1 divergences among closely related speises. Proceedings of the Royal Society of London B: Biological Science, 270(1), 596-599.

Holmes, B. H., Steinke, D., Ward, R. D. 2008. Identification of shark and rays fins using DNA Barcoding. Fisheries Research, 95(2),280288.

IUCN red list of Threatened Species.2016.

http://www.iucnredlist.org/.diaks es februari 2016.

Mundy T.V., and V. Crook. 2013. Into the deep: Implementing CITES measures for commerciallyvaluable sharks and manta rays. Report prepared for the European Commission.

IUCN red list of Threatened Speceies. 2016.

http://www.iucnredlist.org/. diakses februari 2016. 
White W.T., Last, P.R., Stevens, J.D., Yarsley, G.K., Fahmi, Darmadi. 2006. Economycally important shark \& rays Indonesia. Australian Centre for International Agricultural Research, Canberra, Australia.p 2601. 